\title{
変位電流の可視化法と ウェーブレット変換による特徽抽出
}

渡澤 泰之○, 早野 誠治, 斎藤 兆古(法政大学), 堀井 清之(白百合)

\author{
Visualization of Displacement Currents and Its Characteristic \\ Extraction by Wavelets \\ Yasuyuki WATAZAWA, Seiji HAYANO, Yoshifuru SAITO and Kiyoshi HORII
}

\begin{abstract}
Previously, we have proposed a semi-analytical electromagnetic filed computation method, which has made it possible to compute the complex electromagnetic field distributions not obtainable by the conventional numerical schemes, such as finite elements and boundary elements means. However, because of the displacement current, our semi-analytical method encounters some difficulty when analyzing the high frequency electromagnetic field distribution. To overcome this difficulty, we are now developing a new semi-analytical approach taking the displacement currents into account. In the present paper, we visualize the displacement currents by new-semi-analytical method, and its spatial distributing characteristics are extracted by means of wavelets analysis.
\end{abstract}

Keywords: Displacement current, Semi-analysis, Wavelet transform

\section{1.まえがき}

小型・軽量・高性能な個人用計算機（Personal Computer，以下，PC と略記）は，その多機能化と低 価格化により広汎な普及を遂げている，従来，電磁界の 数値解析は極めて大規模の計算となるため、大型計算機 で行われていた。しかし，近年の高性能 PC の普及は電 磁界解析を個人レベルで可能とし, 商用電磁界解析パッ ケージも販売されるに至っている．電磁界解析は，電磁 界を支配する方程式が偏微分方程式であることから，微 分を有限差分で直接置き換える有限差分法（Finite Difference Method)，変分原理に基づく有限要素法

(Finite Element Method) などの数值解析法で行われ る. また, 電磁界が無限遠点まで広がる開領域問題に対 しては, 偏微分方程式の基本解を仮定した境界要素法 （Boundary Elements Method）などの積分方程式形解 法が採用される。しかしながら，このような有限要素法 等に代表される, 電磁界の数値解析法は変位電流を勘案 するにはかなり煩雑な作業とスキルを必要とする，等の 弱点が存在する. 現代の電磁機器の著しい高周波化を考 慮すると、電磁界解析において変位電流を勘案する必要 性に迫られている.

このような現状を踏まえ筆者らは, 有限要素法等とは 全く異なる方法を提唱し, その有効性を従来の数值解析 技術では不可能な問題を解析可能とした ${ }^{1)}$.

本論文は, 有限要素法等では導入が困難な変位電流を,
導体間のキャパシタンスとして考慮した準解析的方法の 新しいモデルを提案する. その結果, 変位電流の可視化 が可能となったことを報告する．また，準解析的方法に よって得られた電流分布をウェーブレット変換による特 徵抽出を試みた結果, 磁界と電界のどちらが系に支配的 であるか判別可能であることを報告する.

\section{2. 準解析的電酸界解析法}

ここでは，本論文で採用するフィルム状導体の例を取 り上げて解析手法の原理を説明する. まず, Fig. 1 に示 す「コ」の字型のフィルム状導体について考える. この フィルム状導体の両端に均一に電圧が印加されていると する.ここで,Fig. 1 (a) に示すように, 電流の通電方向 を勘案して, フィルム状導体を解析的な取り扱いが容易 な $m$ 個の丸型導体へ分割する. 対面する上下の 2 面に対 して側面は十分に小さいので, この面による影響は受け ないものとする．丸型導体モデル中の 2 本を Fig. 1 (b) に示す。

丸型導体の長さはフィルム状導体の一面の長さと同一 とし，断面積はフィルム状導体の断面積の $1 / m$ とする. すなわち, フィルム状導体の体積は丸型導体の体積の総 和に等しい。これは, 丸型導体の数 $m$ を無限大とした場 合にフィルム導体を再現可能とする条件による。 


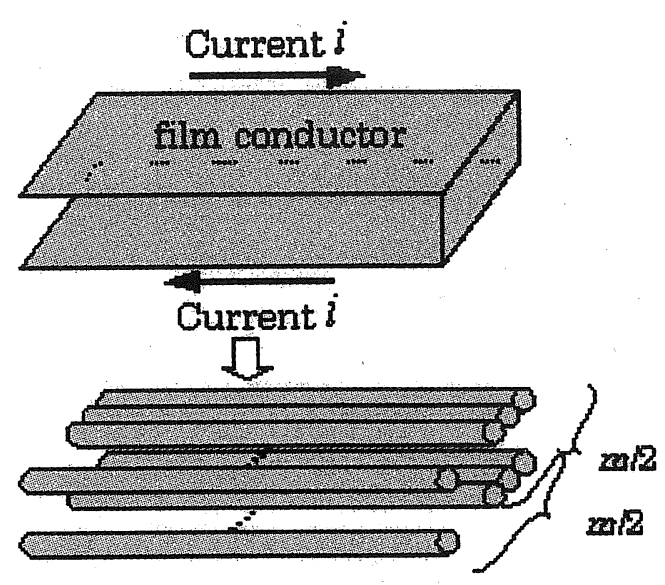

(a)

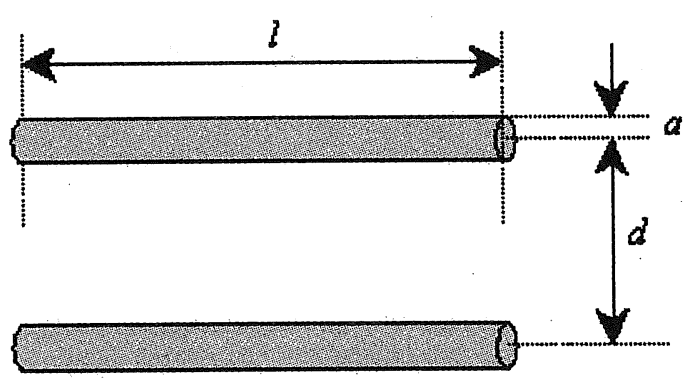

(b)

Fig. 1 Semi-analytical modeling of a film conductor

個々の丸型導体の電気抵抗 $r$ と自己インダクタンス $L$ は解析的に計算可能であり, 次式で与えられる.

$$
\begin{aligned}
& r=\sigma \frac{l}{\pi a^{2}} \\
& L=\frac{\mu_{0}}{8 \pi} l+\frac{\mu_{0}}{2 \pi} l\left[\ln \left(\frac{2 l}{a}\right)-1\right]
\end{aligned}
$$

ここで， $\sigma ， \mathrm{a}, 1, \mu_{0}$ はそれぞれ，抵抗率，丸型導体の半 径, 長さおよび真空中の透磁率である.

Fig. 1 のモデルでは同一丸型導体が平行に配置されて いるから，導体間に磁束による相互結合が存在し，この 相互結合は相互インダクタンス $M_{i j}$ で表される.さらに, 丸型導体間に存在する変位電流はキャパシタンス $C_{i j}$ で 表される. フィルム状導体の面積を $S$ と置くと，それぞ れ次式によって与えられる11.

$$
\begin{aligned}
M_{i j} & =\frac{\mu_{0}}{2 \pi}\left[\ln \left(\frac{l+\sqrt{l^{2}+d_{i j}^{2}}}{\dot{d}_{i j}}\right)-\sqrt{1+\left(\frac{d_{i j}}{l}\right)^{2}}+\frac{d_{i j}}{l}\right] \\
C_{i j} & =\frac{\varepsilon_{0}}{d_{i j}} \frac{S}{m}
\end{aligned}
$$

ここで, 下添え字 $i j$ は第 $i$ 番目と $j$ 番目の丸型導体を 示し, $d_{i j}$ は第 $i$ 番目と $j$ 番目の丸型導体間の距離である.

従って, 分割個数 $m=4$ の場合, Fig. 1 (a) のフィルム 状導体は，Fig. 2 の等価回路によって表される. すなわ ち, フィルム状導体の電流分布解析問題は, Fig. 2 に示 す等価回路を複数個組み合わせた電気回路解析問題へ帰 する．ただし，Fig. 2 の等価回路において，相互インダ クタンス, キャパシタンスについては, 面に関係なくす べての丸型導体間同士に存在するものとする.

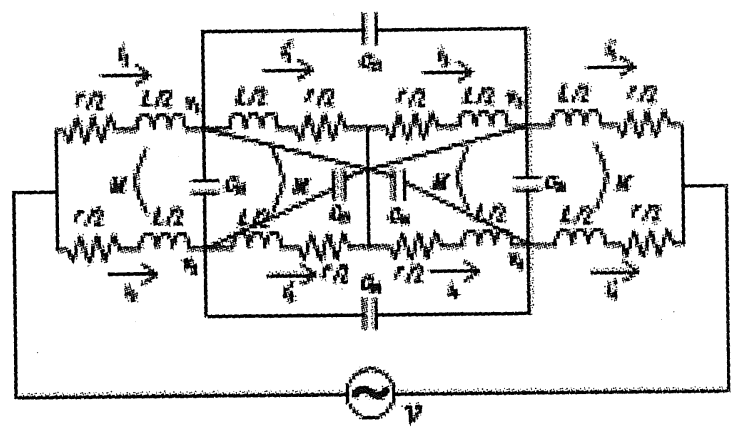

Fig. 2 Equivalent circuit of a film conductor where $m=4$

\section{3. 例 題}

準解析的方法による計算例として, Fig. 1 に示すフィ ルム状導体について考える. 計算で用いたフィルム状導 体の諸定数を Table 1 に示す. まず, Fig. 3 に電流分布 对周波数特性の計算結果を示す 2).

Table 1 Various constants used in the computation of a film conductor

\begin{tabular}{|c|c|}
\hline Material & Copper \\
\hline Resistivity & $1.72 \times 10^{-8}$ \\
\hline $\begin{array}{c}\text { Sizes } \\
\text { (one side) }\end{array}$ & $\begin{array}{c}\text { Width:5[cm] } \\
\text { Length:30[cm] }\end{array}$ \\
\hline $\begin{array}{c}\text { Distance between the } \\
\text { films }\end{array}$ & $0.5[\mathrm{~cm}]$ \\
\hline $\begin{array}{c}\text { Radius of subdivided } \\
\text { conductor }\end{array}$ & $3.98 \times 10^{-3}[\mathrm{~cm}]$ \\
\hline $\begin{array}{c}\text { Number of subdivisions } \\
\text { (one side) }\end{array}$ & $400(200)$ \\
\hline $\begin{array}{c}\text { RMS value of the } \\
\text { impressed voltage }\end{array}$ & $1.0[\mathrm{mV}]$ \\
\hline
\end{tabular}




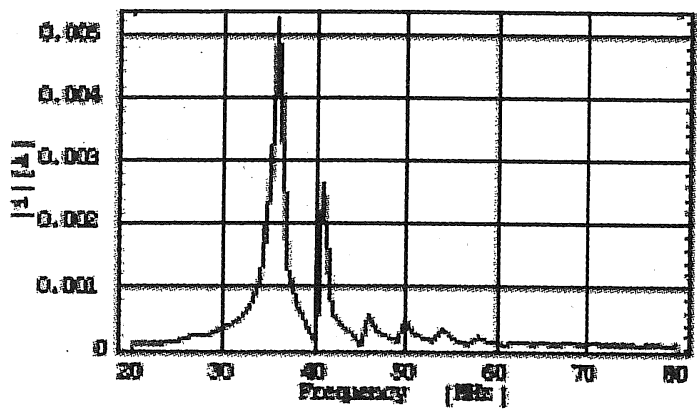

Fig. 3 Current of whole film conductor vs. frequency characteristics

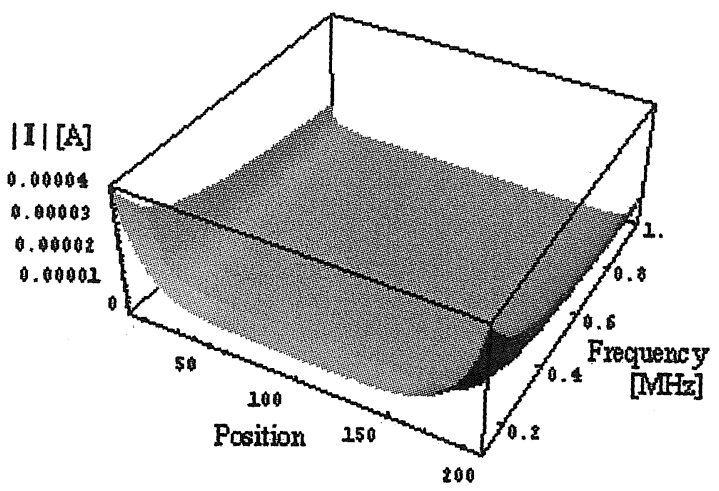

(a) $0.1 \sim 1.0[\mathrm{MHz}]$

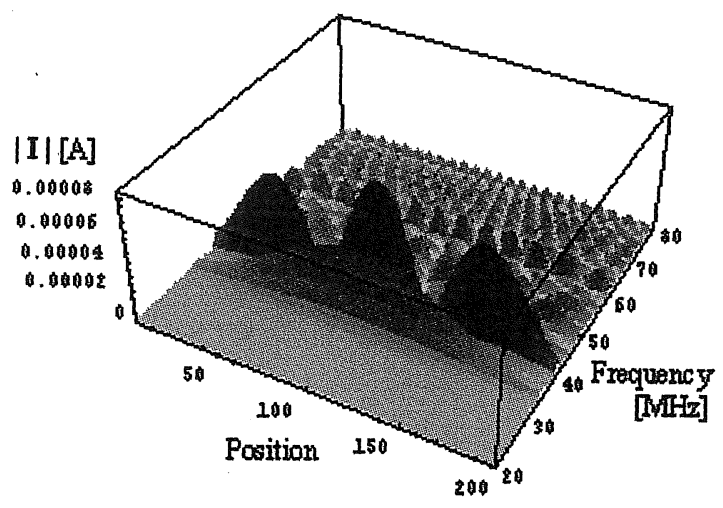

(b) $20 \sim 80[\mathrm{MHz}]$

Fig. 4 Current distribution vs. frequency characteristics

Fig. 3より,明らかに共振現象が確認できる.そして, 共振点は単一ではなく複数個存在する.これは, フィル ムを複数個の丸型導体に分けて分布定数系として計算し ていることに起因する.

また一般に, 磁界は表皮効果を喚起し, 電界は近接効 果を喚起する. Fig. 4 から, 低周波領域では表皮効果に よって電流はフィルムの両端に方寄る. しかし, 高周波 領域では, 近接効果により電流がフィルム導体中心部へ
集中する. 表皮効果と近接勃果の影響がほぼ等しい周波 数帯域で, 共振現象が喚起されることが判る.すなわち, 磁界が系に支配的である周波数から電界が支配的になる 踟界周波数近傍で, 電界と磁界のエネルギーが拮抗し， 共振現象が起こることが解明された.

このように，準解析的方法により置き換えられた等価 回路は, 表皮効果, 近接効果といった電磁界の影響も含 んだモデルであるといえる.

次に, 準解析的方法における Fig. 2 の等価回路のキャ パシタンスに流れる電流, すなわち, 変位電流分布対周 波数特性の計算結果をFig. 5 に示す.

Fig. 5 から, $1[\mathrm{MHz}]$ 以下の低周波領域では変位電流は, Fig. 4 の電流とは逆に周波数が高くなるほど大きい值を とっている. しかしながら，共振周波数以上の高周波領 域では,Fig. 4 の電流とほぼ同じ值をとることが確認出 来る. すなわち、共振周波数以上の高周波領域では, 電 流はほとんど導体間を流れず, キャパシタンスを形成す る空間を流れていることが判る.

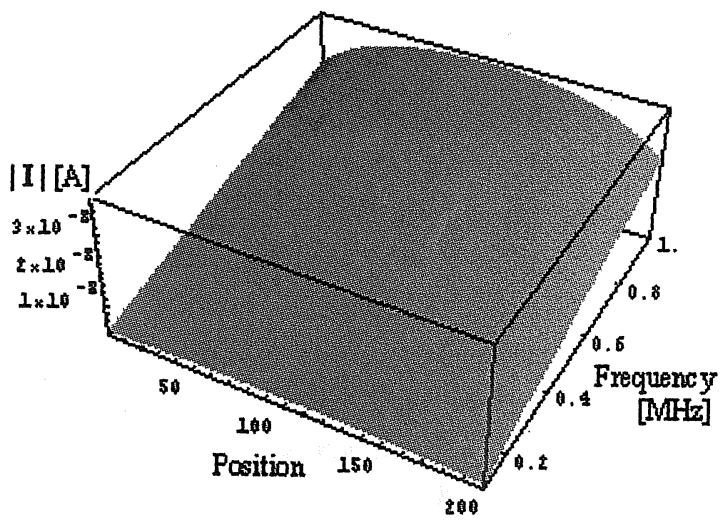

(a) $0.1 \sim 1.0[\mathrm{MHz}]$

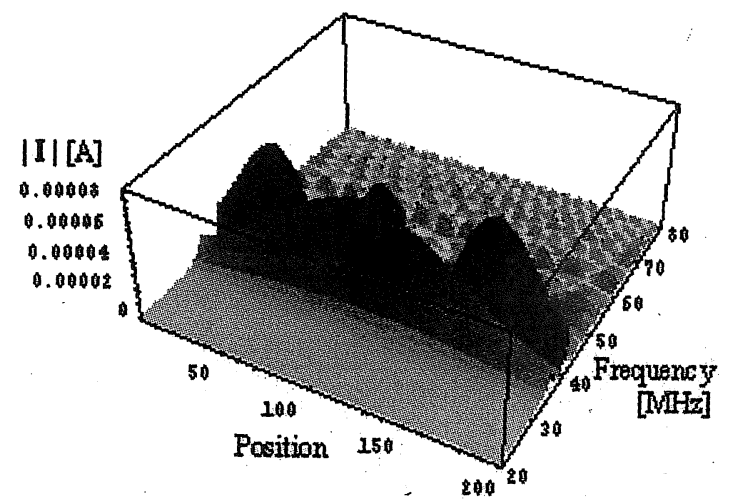

(b) $20 \sim 80[\mathrm{MHz}]$

Fig. 5 Displacement current distribution vs. frequency characteristics 


\section{4. ウェーブレット変換による特徽抽出}

次にウェーブレット変換を用いて, 電流分布の特徵抽 出を行なう. ウェーブレット変換の便宜上, 分割個数は $m=256$ として計算した. Fig. 4 に示した電流分布を各周 波数の 1 次元データとして 1 次元ウェーブレット変換 3),4)を行なった．計算結果を Fig. 6 に示す．計算結果は 各周波数において $0 \sim 1$ に正規化したものである.また, 結果として示した Fig. 6 は基底関数をドビッシーの 4 次とした場合であるが, 他の基底関数の場合も同様の結 果を得ることが出来た.

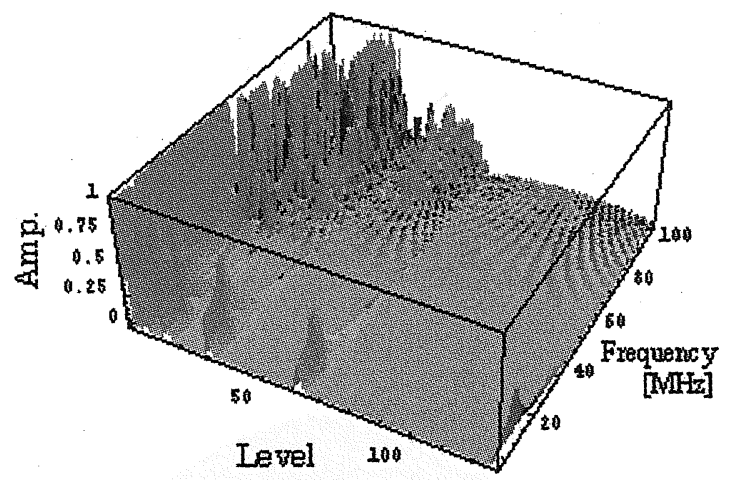

Fig. 6 Result of wavelet analysis of current distribution

Fig. 4 の各周波数における電流分布と Fig. 6 を比較 すると, 表皮効果も起こっていない低周波領域ではウェ ーブレットスペクトラムは高周波成分を含まず，表皮効 果の影響が現れると共に, 高周波成分も現れる. しかし ながら, 近接効果の影響が現れると, 高周波成分は減少 し，共振周波数においてウェーブレットスペクトラムは 高周波成分を含まない. 共振周波数以上の高周波領域に おいては, 比較的低周波成分でウェーブレットスペクト ラムは構成されている.

このように, ウェーブレットスペクトラムから表皮効 果と近接効果のどちらが系に支配的であるかを, 判別可 能であることが判った.

\section{5. まとめ}

本論文では，変位電流の可視化法として変位電流を勘 案した準解析的方法の新しいモデルを提案した.

まず，変位電流を勘案可能なモデルである準解析的方 法について述べた. 準解析的方法では, 細分化された個々 の領域で解析解を適用することにより, 等価回路で表す ことができることを述べ, その等価回路は表皮効果と近 接効果を含む電流分布解析問題が解析可能であることを 示した. さらに, その結果, 変位電流の可視化が可能で あることを示した.

次に，準解析的方法による等価回路から得られた電流
分布を 1 次元ウェーブレット変換により特徴抽出を試み た結果, 系の状態が判別可能であることを述べた.

以上により, 本論文で提唱した電磁界解析のための, 新しいモデルの準解析的方法は, 変位電流の可視化の有 用な方法であることを示した。

\section{荟文献}

1) Takano, T. , Hayano, S., Saito. Y. : Coil impedance computation having arbitrary geometrical shape. IEEE PESC' 98, Vol. 2, May (1998).

2）渡澤泰之, 早野誠治, 斎藤兆古: 準解析的方法による電磁界 解析手法の提案，マグネティックス研究会資料， MAG-00-117 (2000).

3）斎藤兆古: Mathematica によるウェーブレット変換，朝倉 書店 (1996).

4）斎藤兆古: ウェーブレット変換の基礎と応用，朝倉書店 (1998). 